\title{
Dört Kollu Sinyalize Kentsel Kavşaklarda Trafik Kazalarının Sıklığını Etkileyen Faktörlerin İncelenmesi
}

\author{
Murat ÖZEN ${ }^{1}$
}

ÖZ

Kavşaklar kentsel yol ağı üzerinde çok az yer kaplamalarına rağmen trafik kazalarının yoğunlaştığ bölgeleri oluşturmaktadır. Bu çalışmada Mersin kent merkezinde sinyalizasyon ile yönetilen dört kollu 39 kavşakta, 2014-2016 yılları arasındaki sadece taşıtların karıştığı ölümlü/yaralanmalı trafik kazaları ile trafik hacmi, kavşak geometrisi ve trafik kontrol özellikleri arasındaki ilişki incelenmiştir. Bu amaçla Poisson ve negatif binom (NB) regresyon modelleri kullanılmıştır. Sonuçlar kavşağa yaklaşan toplam şerit sayısının artmasının kazaları arttırdığını göstermiştir. Öte yandan, birincil kavşak kollarındaki trafiğin, ikincil kavşak kollarındaki trafiğe oranının atması ve birincil kavşak kollarındaki orta refüj kavşaklardaki kaza sayısını azaltmaktadır.

Anahtar Kelimeler: Sinyalize kentsel kavşak, kaza sıklığı, poisson regresyon, negatif binom regresyon.

\begin{abstract}
Investigation of the Factors Affecting the Crash Frequency at Four-Legged Signalized Urban Intersections -

Although intersections constitute a little space on the urban road network, they are the areas where traffic crashes are concentrated. In this study, the relationship between traffic volume, intersection geometry, traffic control characteristics and vehicular fatal/injury traffic crashes (without pedestrians) were examined for 39 four-legged signalized intersections in the city center of Mersin during 2014 to 2016. For this purpose, Poisson regression and negative binomial (NB) regression models were used. The results showed that total number of approach lanes increases the intersection crashes. On the other hand, the increase in ratio of traffic volumes between primary and secondary intersection legs reduces the intersection crashes. The presence of median on primary intersection legs also reduces the number of crashes.
\end{abstract}

Keywords: Signalized urban intersection, crash frequency, poisson regression, negative binomial regression.

\footnotetext{
Not: Bu yazı

- Yayın Kurulu'na 7 Ocak 2019 günü ulaşmıştır. 23 Temmuz 2019 günü yayımlanmak üzere kabul edilmiştir.

- 31 Temmuz 2020 gününe kadar tartışmaya açıktır.

- https://dx.doi.org/10.18400/tekderg.509128
}

1 Mersin Üniversitesi, İnşaat Mühendisliği Bölümü, Mersin - ozen.murat@mersin.edu.tr https://orcid.org/0000-0002-1745-7483 


\section{GíRiş}

2017 yılında Türkiye'de 1,2 milyon trafik kazası meydana gelmiştir. Bu kazaların 182.669 tanesi ölümlü/yaralanmalı olup, bu kazalarda 7.427 kişi hayatını kaybetmiş ve 300.000'den fazla kişi yaralanmıştır [1]. Yaşanan ölümlü/yaralanmalı trafik kazalarının \%74'ü, ölümlerin ise \%52'si kentsel alanlarda meydana gelmiştir. Kentsel alanlardaki kazaların \%45'i yol ağ1 üzerinde çok az yer kaplamasına rağmen kavşaklarda gerçekleşmiştir [2]. Bu durum Türkiye'de trafik güvenliği konusunda kentsel kavşaklara öncelik verilmesi gerektiğini ortaya koymaktadir.

Literatürde kavşaklarda meydana gelen kazalar ile geometrik tasarım, trafik akım ve arazi kullanım özellikleri arasındaki ilişkiyi inceleyen birçok çalışma bulunmaktadır [3-9]. Türkiye'de bu konudaki çalışmalar oldukça sınırlıdır. Yakın geçmişte, Kaygısız ve Sümer [10] kentsel kavşaklardaki elektronik denetim sistemlerinin, Kaygısız ve Şenbil [11] kentsel alanlardaki kavşak tiplerinin trafik kazaları üzerindeki etkisi incelemiştir. Sinyalize kavşaklarla ilgili diğer çalışmalarda sürücü davranışlarının sinyalize kavşak başarımı üzerindeki etkisi ve doygun akım değerleri incelenmiştir [12-13]. Fakat Türkiye'de kavşaklardaki trafik hacmi, geometrik özellikler ve hız limitleri gibi birçok faktörün trafik güvenliğine etkisini bir arada inceleyen bir çalışma bulunmamaktadır. Bu çalışmada bu eksikliğin giderilmesi amaçlanmaktadır. Bu amaçla Mersin kent merkezinde seçilen dört kollu 39 sinyalize kavşakta, trafik hacmi, kavşağa yaklaşan şerit sayısı, sinyalizasyon sisteminin faz sayısı ve süresi, maksimum yeşil süresi, kavşak çarpıklık açısı, kavşak büyüklüğü, kavşak bölgesindeki nüfus yoğunluğu, kavşak kollarının fiziksel sınıflandırması, hız limitleri, kavşak merkezinde yuvarlak ada ve kavşak kollarında refüj bulunması gibi faktörlerin ölümlü/yaralanmalı kaza sıklığı üzerindeki etkisi incelenmiştir. Literatürde Poisson ve negatif binom (NB) kesikli regresyon modelleri farklı varyasyonlarıla bu tür çalışmalarda sıklıkla kullanılmıştır. Benzer şekilde bu çalışmanın modelleme aşamasında Poisson ve NB regresyon modelleri tercih edilmiştir. Bu konudaki geçmiş çalışmalarda (sadece yaya kazalarını inceleyen çalışmalar hariç) kavşaklardaki tüm kazaların birlikte incelendiği görülmektedir. Bu çalışmada literatürden farklı olarak sadece taşıtların karıştığı kazalar ele alınmıştır. Çalışmanın sonuçlarının trafik güvenliği açısından problemli sinyalize kavşakların belirlenmesinde ve kaza sıklığının azaltılmasında yardımcı olması beklenmektedir.

Bu çalışma altı bölümden oluşmaktadır. Bölüm 2'de kavşaklardaki trafik güvenliği ile ilgili literatür özetlendikten sonra, Bölüm 3'de trafik kazalarının modellemesinde kullanılan yöntemler incelenmiştir. Bölüm 4'de çalışma kapsamında kullanılan modeller anlatılmıştır. Bölüm 5'de çalışma sonuçları ortaya konduktan sonra Bölüm 6'da sonuç ve öneriler tartışılmıştır.

\section{LITERATÜR TARAMASI}

Trafik kazalarının kavşaklarda yoğunlaşmasının en önemli nedeni bu noktalarda taşıtlar ve yayalar arasındaki etkileşimin artmasıdır [4]. Doğru geometrik tasarım ve uygun trafik kontrol yöntemi ile hem kavşaklardaki trafik kazalarının önüne geçilebileceği gibi hem de kapasite kayıpları önlenebilir [14]. Literatürde kavşaklardaki trafik kontrol yöntemi üzerine yapılan çalışmalarda farklı sonuçlar elde edilmiştir. Düşük trafik hacmindeki caddelerde, tüm kollara yerleştirilen dur levhası ile yönetilen kavşakların, sinyalizasyon sistemi veya sadece 
iki kola yerleştirilen dur levhası ile yönetilen kavşaklara göre trafiği yavaşlatmada daha başarılı olduğu bulunmuş̧ur [15-16]. Persuad vd. [17] kentsel alanlardaki düşük hacimdeki sinyalize kavşakların, tüm kollara yerleştirilen dur levhası ile yönetilen kavşaklara dönüştürülmesi durumunda yaya kazalarının $\% 25$ oranında azaldığını göstermiştir. Öte yandan, doğru tasarlanmış sinyalizasyon sistemlerinin trafik akımındaki gecikmeleri azalttığını, farklı trafik akımları ve yol kullanıcıları arasındaki çakışmaları yok ettiğini ve bunun sonucunda kaza riskini azaltarak, kavşak kapasitesini arttırdığı vurgulanmıştır $[4,18$ 19]. Elvik vd. [20] sinyalizasyon sistemlerinin trafik kazalarını üç kollu kavşaklarda \%15, dört kollu kavşaklarda ise \%30 oranında azalttığını söylemiştir. Greibe [21] sinyalizasyon sistemlerinin toplam kaza sayısını değiştirmediği, ölümlü/yaralanmalı kaza sayısını ise istatistiksel olarak anlamlı olmayan seviyede azalttığı sonucuna ulaşmıştır.

Kavşak geometrik tasarımı üzerine yapılan çalışmalarda dört kollu kavşakların bulunduğu bölgelerdeki kaza oranlarının üç kollu kavşakların bulunduğu bölgelere göre daha yüksek olduğu görülmüştür [22-24]. Gluck vd. [25] ve Vogt [26] kavşaklardaki sola dönüş şeridinin trafik güvenliği üzerindeki olumlu etkisini vurgulamıştır. Sağa dönüş şeritleri için ise farklı sonuçlar elde edilmiştir. Wang vd. [5] ve Bauer vd. [27] sağa dönüş şeritlerinin olumlu etkisinden bahsederken, Vogt ve Bared [28] sağa dönüş şeritlerinin trafik kazalarını arttırdığ söylemiştir. Literatürde modern dönel kavşakların geleneksel kavşaklara (sinyalize veya dur kontrollü) göre daha güvenli olduğu belirtilmektedir [3,14,29]. Günümüzde birçok ülkede geleneksel kavşaklar yerine modern dönel kavşaklar tercih edilmeye başlanmışıtır [30-34]. Herhangi bir trafik sinyalizasyon sistemi veya dur levhası bulunmayan ve kavşağa giren araçların kavşak içinde dönüş yapan araçlara yol vermesi ilkesine göre çalışan modern dönel kavşakların daha güvenli olması, kesişen trafik akımı sayısının azalması ve kavşağa giren sürücülerin yavaşlamak zorunda kalması ile açıklanmaktadır [35-37]. Gerçekleş̧irilen öncesonra analizlerinin büyük bir kısmında modern dönel kavşakların hem toplam kaza sayısını hem de bu kazaların şiddetini ciddi oranda düşürdüğü bulunmuştur [31-33]. Öte yandan, Brown [34] modern dönel kavşakların kaza şiddetini önemli derecede azaltmasına rağmen, toplam kaza sayısını çok fazla değiştirmediğini, Elvik [38] modern dönel kavşakların maddi hasarlı kaza sayısını arttırabildiğini ve bu durumun göz ardı edilmemesi gerektiği sonucuna ulaşmıştır. Kavşak geometrisi ile ilgili bir diğer önemli özellik kavşak çarpıklık açısıdır. Kavşak çarpıklık açısı kavşak kolları arasındaki ölçülen açının 90 dereceden farkının mutlak değeri olarak tanımlanmaktadır [39]. Geçmiş çalışmalar yüksek çarpıklık açısına sahip kavşaklardaki görüş problemlerinin kaza oranlarını yükselttiğini belirtmektedir [40-41]. Buna paralel olarak AASHTO [42] dört kollu kavşaklarda 30 dereceden büyük çarpıklık açısı önermemektedir.

Farklı kavşak türlerinde trafik güvenliğine etki eden faktörleri araştıran birçok çalışma bulunmaktadır. Bu çalışmalarda sinyalize kavşaklarda meydana gelen kazaların 400 metreye kadar çevresindeki arazi kullanım, demografik ve sosyoekonomik özelliklerden etkilendiği ortaya çıkmıştır [8,43]. Ladron de Guevara vd. [44] bir bölgedeki kavşak yoğunluğu $\left(\mathrm{kavşak} / \mathrm{km}^{2}\right)$ ile kazası sayısı arasında negatif ilişki olduğunu göstermiştir. Greibe [21] trafik hacminin kentsel alanlardaki sinyalize kavşaklardaki kaza sayısını etkileyen en önemli faktör olduğunu bulmuştur. Lyon vd. [45] kentsel alanlardaki sinyalize kavşaklarda trafik akımının yanı sıra yaya akımı ve kavşağa yaklaşan toplam şerit sayısının trafik güvenliği üzerinde etkili olduğunu göstermiştir. Kumara ve Chin [46] üç kollu sinyalize kavşaklardaki toplam trafik hacmi, sola dönen trafik hacmi, sinyalizasyon sistemindeki faz sayısı, görüş mesafesi, kavşaktaki trafik kameraları, kavşak kollarındaki refüj korkulukları ve eğim gibi birçok 
faktörün kaza sayısı üzerindeki etkisini bulmuştur. Wang vd. [5] dört kollu kavşaklarda ağır taşıt trafiği, kavşak kollarındaki toplam şerit sayısı, sinyalizasyon sisteminin faz sayısı, hız limiti ve kavşağın bulunduğu bölgedeki nüfus arttıkça kaza sayısının arttığı sonucuna ulaşmıştır. Oh vd. [47] kavşak tipinden bağımsız olarak, trafik akım özelliklerinin kavşaklardaki kaza sayısını; kavşak geometrik özelliklerinin ise meydana gelen kazaların tipini etkilediğini belirtmiştir.

Literatürde bazı çalışmalar sadece kavşaklardaki yaya kazalarına odaklanmıştır. Florida'da yapılan bir çalışmada yaya ve sürücü demografik özellikleri ile çevresel faktörlerin, sinyalize kavşaklardaki yaya kazalarının şiddeti üzerinde etkili olduğu bulunmuştur. Bu çalışmada ayrıca kavşaklardaki trafik hacmi ile yaya kazası sayısı arasında doğrusal ilişki olduğu sonucuna ulaşmıştır [48]. Torbic vd. [49] ve Brude ve Larsson [50] ise yaya hacmi ile yaya kazası sayısı arasında doğrusal ilişki olduğunu söylemiştir. Buna ek olarak, Torbic vd. [49] kavşaklardaki yol genişliğinin ve birincil kavşak kollarındaki trafik hacminin ikincil kavşak kollarındaki trafik hacmine oranın artmasının yaya kazalarını arttığını bulmuştur.

\section{TRAFIK KAZALARININ SIKLIĞININ MODELLENMESI}

Literatürde kaza sıklığını etkileyen faktörlerin belirlenmesinde farklı yöntemler kullanılmaktadır. 1990 öncesi çalışmalarda doğrusal regresyon modelleri kullanılmıştır [5152]. Kaza verileri negatif değerler almayan, kesikli bir rassal değişkendir. Doğrusal regresyon modelleri ise kaza verilerinin normal dağılan bir değişken olduğu kabulüne dayanır. Bu nedenle, doğrusal regresyon modelleri kullanılarak yapılan tahminlerde negatif kaza sonuçları gibi, kaza verilerinin doğasına uygun olmayan sonuçlar ortaya çıkabilmektedir [53].

Mio ve Lum [54] kesikli regresyon modelleri kullanılarak trafik kazaları ile bağımsız değişkenler arasındaki ilişkinin daha iyi yansıtılacağını söylemiştir. Poisson regresyonu en temel kesikli regresyon modeli olup, araştırmacılar tarafından sıklıkla tercih edilmektedir [55]. Poisson regresyonu, ortalamanın varyansa eşit olduğu kabulüne dayanır [56]. Poisson modelinin en büyük eksikliği, verideki yayılımın Poisson modeliyle tahmin edilen yayılımdan büyük olduğu duruma (aşırı yayılım) cevap verememesidir [57]. Bu nedenle kaza verilerinin aşırı yayılım gösterdiği durumlarda NB modeli tercih edilmektedir [5]. Literatürde genel olarak NB regresyon modelinin kaza sıklığı ve kazanın meydana geldiği bölgenin geometrik özellikleri arasındaki ilişkiyi tanımlamada Poisson modeline göre daha başarılı olduğu belirtilmiştir [52,58]. Yakın geçmişte Hu vd. [59] Poisson modeli kullanarak kırmızı 1şık kamerası yaptırımlarının ölümlü kazalar üzerindeki etkisini araştırmıştır. Donnel [60] ise NB modelini kullanarak kavşaklardaki aydınlatmanın trafik güvenliği üzerindeki etkisini incelemiştir. Wong vd. [4] çalışmalarında aşırı yayılım gösteren hafif yaralanmalı kazalar için NB modelini, aşırı yayılım göstermeyen ölümlü/yaralanmalı kazaların için Poisson modelini kullanmıştır. Temel Poisson ve NB modellerine getirilen en önemli eleştiri, kaza sıklığının incelendiği kavşaklarda veya yol kesimlerinde fazla sayıda "sıfır kaza" gözlenmesi durumuna cevap verememesidir. Trafik kazasının gerçekleşmediği (sıfır kaza) kavşakların veya kesimlerin sayısı fazla ise, Poisson ve NB modelleri kullanarak tahmin edilen sıfir kazaya sahip kavşak veya kesim sayısı gerçekte gözlemlenenden fazla çıkmaktadır [8]. Bu tür fazla sayıda "sıfır kaza" noktası içeren çalışmalarda Poisson ve NB modellerinin sıfır yığılmalı versiyonları kullanılmaktadır [61-64]. 
Literatürde kaza sıklığı genel olarak Poisson ve NB modellerinin farklı versiyonlarıyla modellenmektedir [7,65-67]. Bunun dişında yakın geçmişteki bazı çalışmalarda farklı yaklaşımlar kullanılmıştır. Das ve Abdel-Aty [68] gen algoritması kullanarak kavşaklardaki arkadan çarpma kazalarının sıklığını ve şiddetini bir arada inceleyen bir model geliştirmiştir. Wang ve Abdel-Aty [69] genelleştirilmiş tahmin denklemleri ile negatif binom bağlantı fonksiyonlarını birlikte kullanarak kavşaklardaki kazaların zamansal ve mekânsal korelasyonunu araştırmıştır. Zhou vd. [70] kök neden derecesi yöntemi kullanarak kavşakların güvenliğini ölçmüştür. Hells ve Orozova-Bekkevold [71] ise dönel kavşaklardaki bisiklet kaza oranlarını inceleyen çalışmasında tek değişkenli lojistik regresyon analizini kullanmıştır.

\section{ARASTTIRMANIN YÖNTEMI}

$\mathrm{Bu}$ çalışmanın ana hedefi Mersin'de dört kollu sinyalize kavşaklarda sadece taşıtların karıştığı ölümlü/yaralanmalı kazaların sıklığına etki eden faktörleri incelemektir. Çalışmanın modelleme aşamasında benzer çalışmalarda sıklıkla kullanılan Poisson ve NB regresyon modelleri tercih edilmiştir. Çalışma alanında "sıfır kaza" gözlemlenmiş kavşak sayısı çok az sayıda olduğu için bu modellerin temel versiyonları kullanılmıştır (bak Şekil 2).

Poisson modeline göre $i$. kavşakta $n_{i}$ tane kaza meydana gelme olasılığı [72-73]:

$P\left(n_{i}\right)=\exp \left(-\lambda_{i}\right) \lambda_{i}^{n i} / n_{i} !$

Burada $\lambda_{i}$ (Poisson parametresi) $i$. kavşakta beklenen kaza sayısıdır.

$\hat{\lambda}_{i}=\exp \left(\beta_{1} X_{0}+\beta_{1} X_{1}+\beta_{2} X_{2}+\ldots+\beta_{n} X_{n}\right)=\exp \left(\beta X_{i}\right)$

burada $\hat{\lambda}$ parametresi $i$. kavşakta meydana gelmesi beklenen kaza sayısını ifade ederken, $x_{1}$, $x_{2}, \ldots, x_{n}$ kavşağa ait bağımsız değişkenleri ve $\beta_{1}, \beta_{2}, \ldots, \beta_{n}$ bu değişkenlere ait katsayıları ifade etmektedir. Poisson regresyonunda katsayılar maksimum olabilirlik yöntemi ile tahmin edilir. Burada olabilirlik fonksiyonu:

$L(\beta)=\prod_{i} \frac{\exp \left(\beta^{\prime} X_{i}\right)^{n_{i}}\left(\exp \left(-\exp \left(\beta^{\prime} X_{i}\right)\right)\right.}{n_{i} !}$

Maksimize edilecek olabilirlik fonksiyonun logaritması aşağıdaki gibidir.

$\log L=-\sum_{i}-\exp \left(\beta^{\prime} X_{i}\right)+n_{i} \beta^{\prime} X_{i}-\ln \left(n_{i} !\right)$

NB model, Poisson modeline (2) bağımsız hata teriminin eklenmesiyle elde edilmiştir [7273].

$\lambda_{i}=\exp \left(\beta X_{i}+\varepsilon i\right)$

burada $\varepsilon$ i ortalaması 1 ve varyansı $\alpha$ olan gamma dağılımına sahip hata terimidir. Bu durumda koşullu olasılık: 


$$
P\left(n_{i} \mid \varepsilon\right)=\frac{\exp \left[-\lambda_{i} \exp \left(\varepsilon_{i}\right)\left[\lambda_{i} \exp \left(\varepsilon_{i}\right)\right]^{n_{i}}\right.}{n_{i} !}
$$

NB dağılımı koşullu olasılıktan bağımsız olarak ifade edilmek istenirse:

$P\left(n_{i} \mid \varepsilon\right)=\frac{\Gamma\left(\theta+n_{i}\right)}{\left[\Gamma(\theta) \cdot n_{i} !\right]} u_{i}^{\theta}\left(1-u_{i}\right)^{n_{i}}$

burada $u_{i}=\theta\left(\theta+\lambda_{i}\right)$ ve $\theta=1 / \alpha$. Bu durum Poisson modelinin aksine, NB modelinde ortalamanın varyansa eşit olmaması sonucunun doğurur.

$\operatorname{var}\left(n_{i}\right)=E\left(n_{i}\right)\left[1+\alpha E\left(n_{i}\right)\right]$

burada $\alpha$ yayılım ölçütüdür.

\section{5. ÇALIŞMA ALANI VE VERÍLER}

Bu çalışmada 2014-2016 yılları arasında Mersin kent merkezinde sinyalizasyon sistemiyle yönetilen dört kollu 39 sinyalize kavşaktaki sadece taşıtların karıştı̆̆ı ölümlü/yaralanmalı kazalar incelenmiştir (bak Şekil 1). İncelenen kavşakların çalışma süresince trafik yönetim ve geometrik özelliklerinde değişiklik yapılmamış olmasına özen gösterilmiştir. Çalışmanın ilk aşamasında 2014-2016 yılları arasında Mersin'de meydana gelen 17.743 ölümlü/yaralanmalı kazaya ait veriler elde edilmiştir. Bu veriler meydana gelen her bir kaza için kaza tarihini, kaza coğrafi koordinatlarını, kaza tipini ve ölüm/yaralanmaların sayısını içermektedir. Çalışmanın ikinci aşamasında yayaların karıştığı kazalar çalışma kapsamından çıkarılmıştır. Üçüncü aşamada kazaların coğrafi koordinatları ArcGIS 10.0 ortamında yol ağına atanmıştır. Benzer çalışmalarda olduğu gibi, kavşakların merkezinden kavşak kolları boyunca 75 metre içerisindeki kazalar kavşak kazası veya kavşak kaynaklı kaza kabul edilip analizlere dâhil edilmiştir [5,8,74]. Buna göre 2014-2016 yılları arasında incelenen kavşaklarda sadece taşıtların karıştığı 462 ölümlü/yaralanmalı trafik kazası meydana gelmiştir. Şekil 2'de kavşaklardaki ortalama kaza sayılarına ait çubuk grafiği verilmiştir. 39 kavşaktan sadece 2 tanesinde çalışma süresince kaza meydana gelmemiştir. 6 kavşakta yılda ortalama 1 kaza ve 4 kavşakta yılda ortalama 2 kaza meydana gelmiştir. Yılda ortalama 8 ve üzeri kaza meydana gelen 2 kavşak bulunmaktadır. Buna göre kavşak başına yılda 3,95 ölümlü/yaralanmalı kaza meydana gelmiştir. Literatürdeki çalışmalarda bu değer 0,90 ile 3,69 arasında değişmektedir [6,8,9,46,53,71].

Geliştirilen Poisson ve NB regresyon modellerinde anlamlılığı test edilen sürekli ve kategorik değişkenlere ait tanımlayıcı istatistikler Tablo 1 ve 2'de sunulmuştur. Literatürde trafik hacminin kavşak kazalarındaki etkisini incelemek için kavşağa tüm kollardan giren Ortalama Günlük Trafik (OGT) ve Yıllık Ortalama Günlük Trafik (YOGT) değişkenleri kullanılmıştır $[4,5,56]$. Bu çalışmada trafik hacim değişkenlerini elde etmek için 2015 yıllında Mersin Ulaşım Ana Planı Revizyonu kapsamında incelenen 39 kavşakta sabah, öğle ve akşam saatlerinde gerçekleştirilen trafik sayımlardan yararlanılmıştır [75]. Bu sayım değerleri birim otomobil eşdeğeri (BOtE) olarak yayınlandığı için, çalışma kapsamında hacim değerlerinde BOtE birimi kullanılmıştır. Bu sayımlar kullanılarak önce her bir kavşağa zirve saate giren trafik belirlenmiştir. Daha sonra bu değerler, Highway Capacity Manual'da belirtilen 
dönüşüm katsayıları kullanılarak, kavşağa tüm kollardan giren YOGT değerine (TYOGT) dönüştürülmüştür [76]. Benzer şekilde, kavşağa birincil kavşak kollarından giren BOtE (AYOGT) ve ikincil kavşak kollarından giren BOtE (IYOGT) değerleri hesaplanmıştır. Aynı yaklaşım Montella [77] tarafından kavşaklardaki trafik güvenliği üzerine yapılmış bir çalışmada kullanılmıştır. Çalışma kapsamındaki kavşaklarda, trafik akımının yüksek olduğu doğrultudaki kavşak kolları birincil kavşak kolları, diğerleri ise ikincil kavşak kolları olarak kabul edilmiştir (AYOGT+IYOGT=TYOGT). Bir başka ifadeyle, bu ayırım yapılırken kavşak kollarının fiziksel sınıflandırılması göz önüne alınmamıştır, sadece trafik hacmi göz önüne alınarak birincil ve ikincil kavşak kolları belirlenmiştir. Modelleme aşamasında kullanılmak üzere AYOGT'nin IYOGT'ye oranı (OYOGT) ve AYOGT ile YOGT arasındaki fark (FYOGT) değişkenleri oluşturulmuştur. Hacim değerleri kavşağa yaklaşan şerit sayıları ile normalize edilerek de kullanılmıştır. Literatürdeki çalışmalara benzer şekilde, hacim ve şerit başına düşen hacim değerlerinin logaritmaları geliştirilen modellerde test edilmek üzere hesaplanmıştır [4,5]. Hızın trafik güvenliği üzerindeki etkisini incelemek için ise birincil ve ikincil kavşak kollarındaki hız limitleri kullanılmıştır (bak Tablo 1 ve 2).

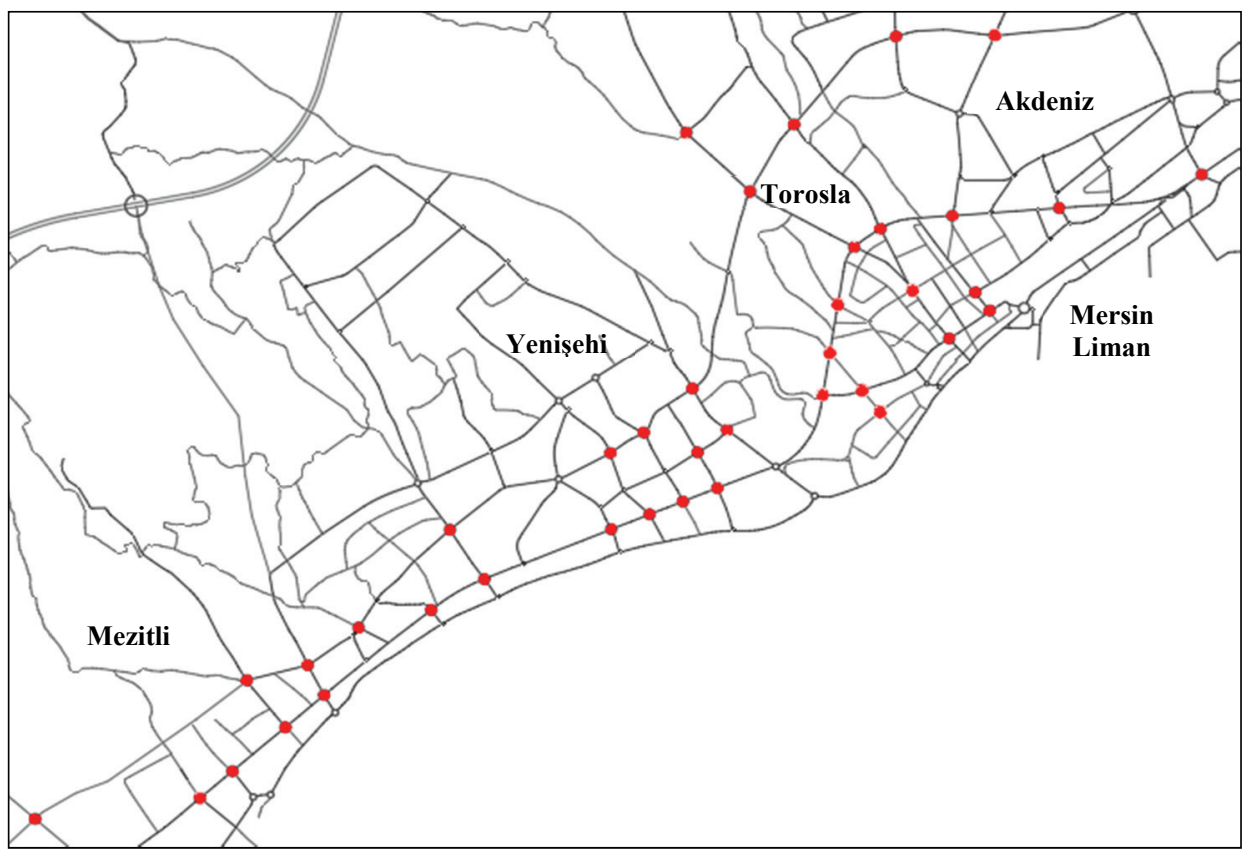

Şekil 1 - Çalışma kapsamında incelenen kavşaklar 


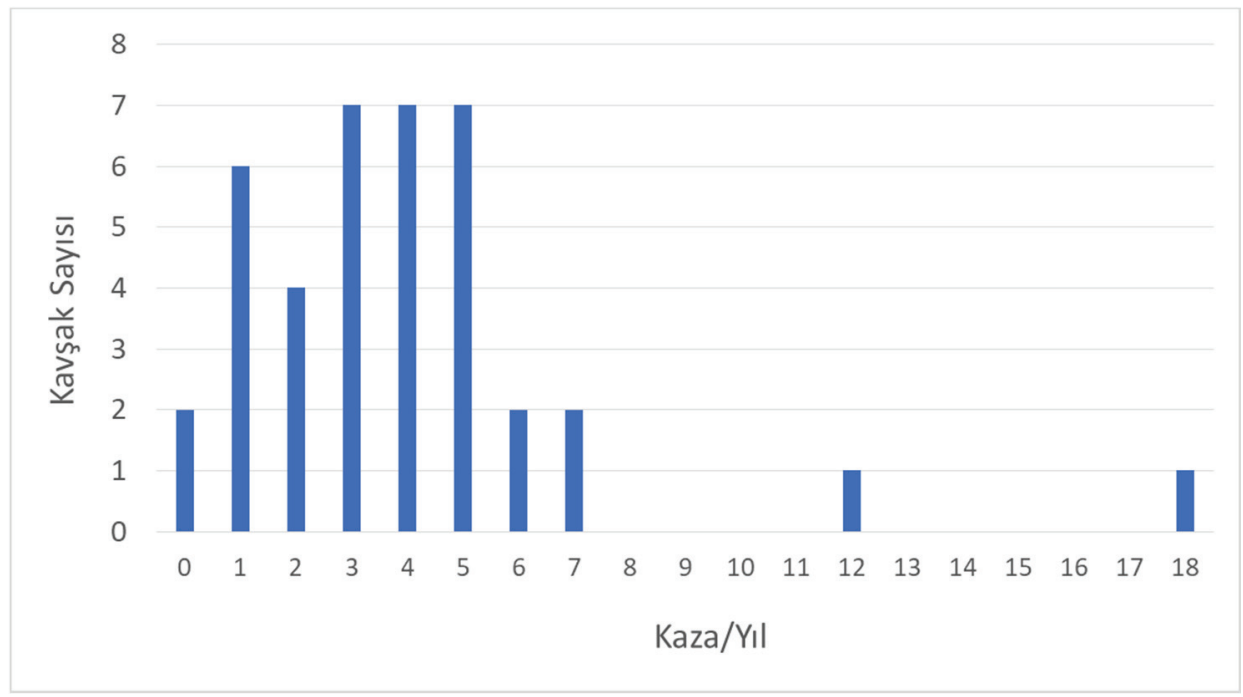

Şekil 2 - Kavşaklardaki ortalama kaza sayıları

Tablo 1 - Sürekli değişkenlere ait tanımlayıcı istatistikler

\begin{tabular}{lrrrr}
\hline Sürekli Değişken & Ort. & $\begin{array}{c}\text { En } \\
\text { Küçük }\end{array}$ & $\begin{array}{c}\text { En } \\
\text { Büyük }\end{array}$ & $\begin{array}{c}\text { S. } \\
\text { Sapma }\end{array}$ \\
\hline Taşıtlar arasındaki kaza (Kaza/Kavşak) & 3,95 & 0 & 18 & 3,25 \\
TYOGT: Kavşağa tüm kollardan giren YOGT (BOtE) & 40.797 & 13.491 & 69.033 & 14.930 \\
AYOGT: Kavşağa birincil kollardan giren YOGT (BOtE) & 29.068 & 8.052 & 51.121 & 10.242 \\
IYOGT: Kavşağa ikincil kollardan giren YOGT (BOtE) & 11.728 & 3.196 & 31.681 & 7.146 \\
TS: Kavşağa tüm kollardan yaklaşan şerit sayısı & 9,2 & 4 & 12 & 2,1 \\
AS: Kavşağa birincil kollardan yaklaşan şerit sayısı & 5,5 & 2 & 6 & 1,2 \\
IS: Kavşağa ikincil kollardan yaklaşan şerit sayısı & 3,7 & 1 & 6 & 1,2 \\
MY: Maksimum yeşil süresi (sn.) & 36,5 & 25 & 81 & 11,1 \\
C: Sinyalizasyon döngü süresi (sn.) & 89,5 & 55 & 128 & 21,3 \\
OM: Ortalama kavşak mesafesi (m.) & 577 & 200 & 100 & 206 \\
KCA: Maksimum kavşak çarpıklık açısı (derece) & 13,4 & 1 & 40 & 10,9 \\
KA: Kavşak alanı (hektar) & 0,9 & 0,1 & 14 & 2,4 \\
NY: Nüfus yoğunluğu (kişi/hektar) & 158,7 & 20,9 & 338,7 & 64,6 \\
OYOGT: AYOGT/IYOGT & 3,2 & 1,1 & 9,9 & 2,0 \\
FYOGT: AYOGT-IYOGT & 17.340 & 1.879 & 40.066 & 9.436 \\
STYOGT: TYOGT/TS (BOtE/şerit) & 4.390 & 2.940 & 7.363 & 1.110 \\
SAYOGT: AYOGT/AS (BOtE/şerit) & 5.270 & 2.861 & 9.170 & 1.384 \\
SIYOGT: IYOGT/IS (BOtE/şerit) & 3.159 & 799 & 5.765 & 1.349 \\
\hline
\end{tabular}


Tablo 1 - Sürekli değişkenlere ait tanımlayıcı istatistikler (devam)

\begin{tabular}{lrrrr}
\hline Sürekli Değişken & Ort. & $\begin{array}{c}\text { En } \\
\text { Küçük }\end{array}$ & $\begin{array}{c}\text { En } \\
\text { Büyük }\end{array}$ & $\begin{array}{c}\text { S. } \\
\text { Sapma }\end{array}$ \\
\hline Log(TYOGT) & 10,5 & 9,5 & 11,1 & 0,4 \\
Log(AYOGT) & 10,2 & 9,0 & 10,8 & 0,4 \\
$\log ($ IYOGT) & 9,2 & 8,1 & 10,4 & 0,6 \\
$\log ($ STYOGT) & 8,4 & 8,0 & 8,9 & 0,2 \\
$\log ($ SAYOGT) & 8,5 & 8,0 & 9,1 & 0,3 \\
$\log ($ SIYOGT) & 8,0 & 6,7 & 8,7 & 0,5 \\
\hline
\end{tabular}

Tablo 2 - Kategorik değişkenlere ait tanımlayıcı istatistikler

\begin{tabular}{llrr}
\hline Kategorik Değişken & \multicolumn{1}{c}{ Seviye } & Gözlem Sayıs & \multicolumn{1}{c}{$\%$} \\
\hline AH: Birincil kavşak kollarındaki hız limiti & $0,70 \mathrm{~km} / \mathrm{sa}$ & 9 & 23,1 \\
& $1,50 \mathrm{~km} / \mathrm{sa}$ & 30 & 76,9 \\
IH: İkincil kavşak kollarındaki hız limiti & $0,70 \mathrm{~km} / \mathrm{sa}$ & 1 & 2,6 \\
& $1,50 \mathrm{~km} / \mathrm{sa}$ & 38 & 97,4 \\
AR: Birincil kavşak kollarında refüj bulunması & 0, Yok & 3 & 7,7 \\
& 1, Var & 36 & 92,3 \\
IR: İkincil kavşak kollarında refüj bulunması & 0, Yok & 13 & 33,3 \\
& 1, Var & 26 & 66,7 \\
OA: Kavşakta yuvarlak orta ada bulunması & 0, Yok & 20 & 51,3 \\
& 1, Var & 19 & 48,7 \\
KF: Kavşak kollarının fiziksel sınıflandırması & 0, Farklı & 31 & 79,5 \\
KH: Kavşak kollarının hız limiti & 1, Aynı & 8 & 20,5 \\
& 0, Farklı & 29 & 74,3 \\
F: Sinyalizasyon sistemindeki faz sayısı & 1, Aynı & 10 & 25,7 \\
& 0,2 Faz & 15 & 38,5 \\
& 1,3 Faz & 8 & 20,5 \\
& 2,4 Faz & 16 & 41,0 \\
\hline
\end{tabular}

Literatür bölümünde belirtildiği üzere, trafik akımının yanı sıra kavşakların geometrik ve trafik kontrol özellikleri, arazi kullanımı kazalarının sıklığını etkilemektedir. Bu amaçla, sinyalizasyon faz sayısının, maksimum yeşil ve döngü süresinin, kavşak merkezinde yuvarlak orta ada bulunup bulunmamasının, kavşak çarpıklık açısının, kavşağa yaklaşan şerit sayısının, birincil/ikincil kavşak kollarının fiziksel sınıflandırılmasının ve bu kollarda refüj bulunup bulunmamasın etkisi incelenmiştir. Kavşak çarpıklık açısının etkisini değerlendirmek için her bir kavşakta kavşak kolları arasında ölçülen maksimum sapma açısı değişkeni kullanılmıştır. Fiziksel sınıflandırma yapılırken kavşak kollarındaki şerit sayısı (3x2, $2 \times 2$ veya $1 \times 2)$ kullanılmıştır. Kavşak büyüklüğünün etkisini incelemek için kavşak alanı değişkeni kullanılmıştır. Kavşak alanı kavşak kollarındaki dur çizgilerinin arasında kalan alan olarak hesaplanmıştır. Kavşak sıklığının etkisini incelemek için ortalama kavşak mesafesi değişkeni kullanılmıştır. Bu değer birincil ve ikincil kavşak kollarındaki bir önceki 
ve sonraki kavşağa olan mesafelerin ortalaması olarak hesaplanmıştır. Kavşak bölgesindeki nüfus yoğunluğunun etkisi için ise kavşağın bulunduğu mahallede hektar başına düşen nüfus kullanılmıştır (bak Tablo 1 ve 2).

\section{BULGULAR}

Çoklu regresyon analizi, modelde kullanılan tahmin edici değişkenlerin istatistiksel olarak birbirlerinden bağımsız olması kabulüne dayanır. $\mathrm{Bu}$ nedenle modelde kullanılması düşünülen değişkenlerin bu varsayımı sağlayıp sağlamadığı kontrol edilmelidir. Tablo 3'de görüldüğü gibi bazı kesikli değişkenler arasında yüksek korelasyon olduğu bulunmuştur $(|r|>0,60)$. Örnek olarak, TYOGT değişkeni ile TS değişkeni arasında $(r=0,71)$ ve STYOGT değişkeni ile SAYOGT değişkeni arasında $(r=0,89)$ yüksek korelasyon mevcuttur. Kesikli regresyon modellerinde Akaike bilgi ölçütleri (AIC), Bayes bilgi ölçütleri (BIC), Pearson ki-kare değerlerinin en küçük; log olabilirlik değerinin en büyük olduğu modelin bağımsız değişkenlerinin bağımlı değişkeni daha iyi yansıttığı kabul edilmektedir. Bu kriter göz önünde bulundurularak aralarında yüksek korelasyon olan değişkenlerden hangilerinin geliştirilen modellerde kalacağı belirlenmiştir. Yine bu kritere bağlı olarak, IBM SPSS Statistics 24 ortamında geliştirilen en iyi Poisson ve NB regresyon sonuçları Tablo 4'de sunulmuştur.

En iyi Poisson regresyonu sonuçlarına göre, kavşağa tüm kollardan yaklaşan toplam şerit sayısı (TS) $(p=0,000)$, birincil kavşak kollarındaki YOGT değerinin ikincil kavşak kollarındaki YOGT değerine oranı (OYOGT) $(p=0,031)$, birincil kavşak kollarında refüj bulunup bulunmaması (AR) $(p=0,010)$ meydana gelen kaza sayısını istatistiksel olarak anlamlı bir şekilde açıklamaktadır. Bu değişkenlerin yanı sıra, kavşaktaki sinyalizasyon sistemindeki faz sayısı $(\mathrm{F})(p=0,184)$ anlamlı bir parametre olmasa da geliştirilen modelin uyum iyiliğini arttırmaktadır (daha küçük AIC, BIC, Pearson ki-kare değeri; daha büyük log olabilirlik değeri). İncelenen dört kollu kavşaklarda kavşağa tüm kollardan yaklaşan şerit sayısının artması (TS) kaza sayısını anlamlı olarak arttırmaktadır $(\beta=0,409)$. Kavşağa birincil kavşak kollarından giren birim otomobil eşdeğerinin (AYOGT), ikincil kavşak kollarından giren birim otomobil eşdeğerine (IYOGT) oranı olan OYOGT arttıkça kaza sayısı anlamlı biçimde azalmaktadır $(\beta=-0,122)$. Birincil kavşak kollarındaki orta refüj bulunan kavşaklarla kıyaslandığında, orta refüj bulunmayan kavşaklarda kaza sayısı anlamlı derecede artmaktadır $(\beta=1,648)$. Dört fazlı sinyalizasyon sistemiyle yönetilen kavşaklarla kıyaslandığında, sinyalizasyon sisteminin faz sayısındaki azalma anlamlı olmasa da kaza sayısını azaltmaktadır ( 2 faz için $\beta=-0,360 ; 3$ faz için $\beta=-0,041$ ).

Poisson modeli bağımlı değişkenin ortalamasının varyansına eşit olması kabulüne dayanır. Tablo 1'de görüldüğü gibi kavşaklardaki kaza sayısının (bağımlı değişken) ortalaması ile varyansı birbirine eşit değildir. Bu incelenen bağımlı değişkende aşırı yayılım olabileceğinin göstergesidir. Verideki aşırı yayılımı tespit etmek için, Poisson modelinin sapma parametresinin geliştirilen modelin serbestlik derecesi oranı kullanılmaktadır. Bu oranın 1 değerinden uzaklaşma derecesi bağımlı değişkendeki aşırı yayılımı ifade etmektedir. Poisson modeli için bu oran 1,101 bulunmuştur (bak Tablo 4). Bu değer 1'e oldukça yakındır ve veride aşırı yayılım problemi olmadığının göstergesidir. Yine de literatürdeki NB modelinin kaza sıklığı ve kazanın meydana geldiği bölgenin geometrik özellikleri arasındaki ilişkiyi daha iyi yansıttığı görüşüne dayanarak NB geliştirilmiştir [52,58]. Geliştirilen NB regresyon 


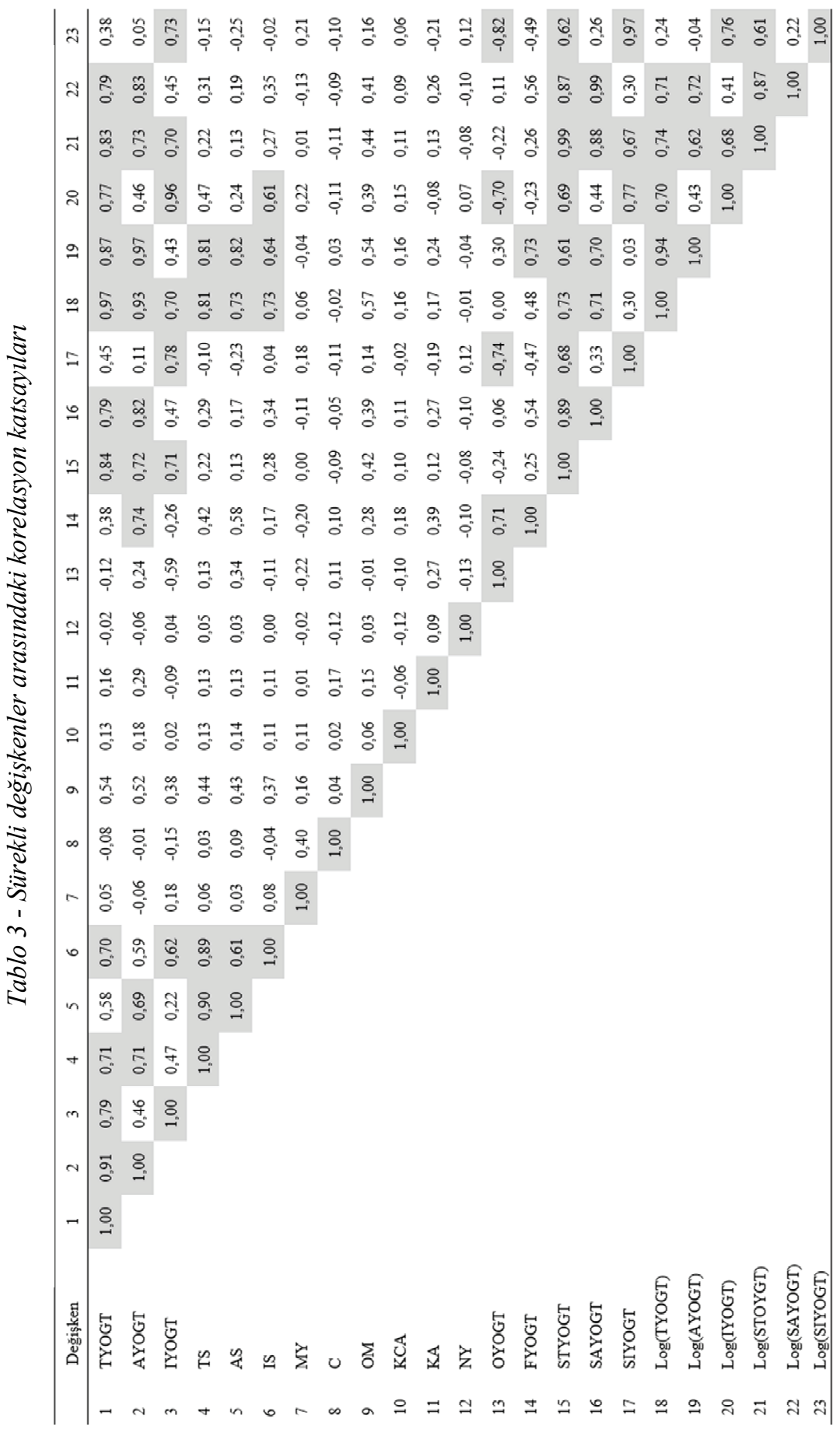


modelinin aşırı yayılım (negatif binom) parametresi 0,001 olarak bulunmuştur (bak Tablo 4). $\mathrm{Bu}$ değerin 0'a uzaklığı verideki aşırı yayılımın bir başka göstergesidir. Buna göre de kavşaklardaki kaza sayıları aşırı yayılım göstermemektedir. Tablo 4'de görüldügü gibi her iki modelin AIC, BIC, Pearson ki-kare ve log olabilirlik değerleri neredeyse aynıdır. Bu nedenle geliştirilen NB modeli anlamlılık düzeyinde bir iyileştirme sağlamamıştır.

Tablo 4 - Poisson ve negatif binom regresyon sonuçları

\begin{tabular}{|c|c|c|c|c|}
\hline \multirow{2}{*}{ Değişkenler } & \multicolumn{2}{|c|}{ Poisson } & \multicolumn{2}{|c|}{ NB } \\
\hline & Katsayı & $\mathrm{p}$ & Katsayı & $\mathrm{p}$ \\
\hline Sabit & $-2,143$ & $0,014 *$ & $-2,140$ & $0,016^{*}$ \\
\hline TS & 0,409 & $0,000 *$ & 0,410 & $0,000 *$ \\
\hline OYOGT & $-0,122$ & $0,031 *$ & $-0,123$ & $0,032 *$ \\
\hline $\mathrm{AR}$ & & $0,010^{*}$ & & $0,012 *$ \\
\hline 0 , Yok & 1,648 & & 1.646 & \\
\hline 1, Var & $0 * *$ & & $0 * *$ & \\
\hline \multirow{5}{*}{$\begin{array}{l}0,2 \mathrm{Faz} \\
1,3 \mathrm{Faz} \\
2,4 \mathrm{Faz}\end{array}$} & & 0,184 & & 0,207 \\
\hline & $-0,360$ & & $-0,360$ & \\
\hline & $-0,041$ & & $-0,040$ & \\
\hline & $0 * *$ & & $0 * *$ & \\
\hline & \multicolumn{2}{|c|}{ Poisson } & \multicolumn{2}{|c|}{ NB } \\
\hline AIC & \multicolumn{2}{|c|}{162,959} & \multicolumn{2}{|c|}{164,958} \\
\hline $\mathrm{BIC}$ & \multicolumn{2}{|c|}{165,584} & \multicolumn{2}{|c|}{168,572} \\
\hline Pearson ki-kare & \multicolumn{2}{|c|}{37,284} & \multicolumn{2}{|c|}{37,169} \\
\hline Log olabilirlik & \multicolumn{2}{|c|}{$-75,450$} & \multicolumn{2}{|c|}{$-75,480$} \\
\hline Yayılım & \multicolumn{2}{|c|}{1,101} & & \\
\hline \multicolumn{3}{|l|}{ Negatif binom } & \multicolumn{2}{|c|}{0,001} \\
\hline
\end{tabular}

Rootogramın kesikli regresyon modellerinin uyum iyiliğinin gösteriminde kullanılan ve geleneksel dağılım grafiğinden daha başarılı olduğu ifade edilen yeni bir tekniktir [78]. Kleiber ve Zeiles [78] üç farklı rootogram arasından asılı (hanging) veya sarkık (suspended) rootogram kullanılmasını önermektedir. Şekil 3'de sarkık rootogram kullanılarak kavşaklarda gözlemlenen kaza sayıları ile tahmin edilen kaza sayıları karşılaştırılmıştır. Burada daha küçük AIC değerine sahip olması açısından Poisson regresyon modellinin sonuçları kullanılmıştır. Burada çubuk grafiği tahmin edilen ve gözlenen kaza sayılarının kareköklerinin farkını göstermektedir. Çizgi grafiği ise tahmin edilen kaza sayısının karekökünü göstermektedir. Çubuk grafiğinin sıfıra yaklaşması modelin uyum iyiliğinin yüksek olduğunu gösterir. Şekil 3'de görüldüğü üzere çubuk grafikleri sıfır noktasından çok fazla uzaklaşmamıştır. Örnek olarak, 7 kavşakta yılda ortalama 5 kaza gerçekleşirken, 
geliştirilen model bu değeri 8 kavşak olarak tahmin etmiştir. Çalışma alanında 1 kavşakta yılda ortalama 18 kaza meydana gelirken, geliştirilen modelde 1 kavşakta 16 kazanın gerçekleşmesi beklenmektedir (bak Şekil 2 ve 3).

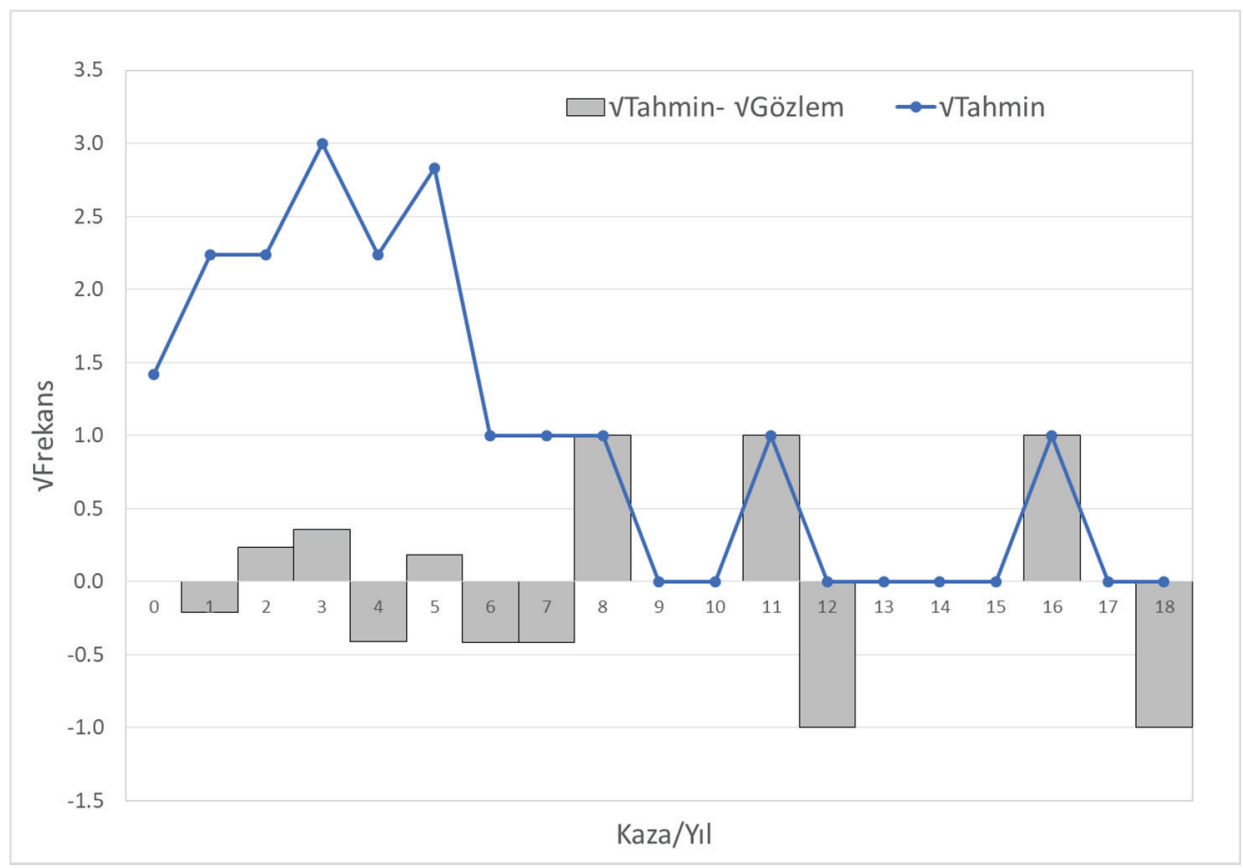

Şekil 3 - Poisson modeline ait sarkık rootogram

\section{SONUÇLAR VE TARTIŞMA}

Literatürdeki geçmiş çalışmalarda kavşaklardaki trafik hacmindeki artışın kaza sayısını arttırdığı bulunmuştur [21,45-46]. Sadece yaya kazalarını inceleyen çalışmalarda ise yaya hacmindeki artışın kavşaklardaki yaya kazalarını arttırdığı sonucuna ulaşılmıştır [49-50]. Buna bağlı olarak hem taşıt trafiği hem de yaya trafiği hacmi kavşak kazaları açısından önem kazanmaktadır. Literatür taraması bölümünde özetlenen çalışmalar incelendiğinde (sadece yaya kazalarını inceleyenler hariç) kavşaklardaki tüm kazaların (taşıtlar arasındaki kazalar ve yaya kazaları) birlikte incelendiği ama modelleme aşamasında yaya trafiğine ait bir parametre kullanılmadığı görülmektedir. Bu çalışmalardaki modellerde sadece trafik akım, yol geometrik ve trafik kontrol özelliklerine ait parametreler kullanılmıştır. Böyle bir durumda kavşaklardaki toplam kaza sayısını etkileyebilecek parametrelerden biri olan yaya trafiğinin etkisi göz ardı edilmektedir. Eğer yaya trafiğini temsil edecek bir parametre bulunamıyorsa, sadece taşıtlar arasındaki kazaların incelenmesi geliştirilen modelin anlamlılığı açısından daha uygun olacaktır. Bu görüş doğrultusunda, bu çalışmada Mersin'de kentsel alanlardaki dört kollu sinyalize kavşaklarda sadece taşıtların karıştığı kazaların sıklığ ile trafik hacmi, kavşak geometrisi, trafik kontrol özellikleri arasındaki ilişki incelenmiştir. İncelenen kavşaklardaki yaya yoğunluğuna ait bir parametre kullanılamadığı için yaya kazaları çalışma kapsamından çıkarılmıştır. Modelleme aşamasında bu konudaki 
çalışmalarda sıklıkla kullanılan Poisson ve NB modellerinin temel versiyonları tercih edilmiştir. Bu modellerin temel versiyonlarının kullanılmasının sebebi kaza verilerinin sıfır yığglmalı olmamasıdır. Kullanılan kaza verileri aşırı yayılım göstermediği için Poisson ve NB modellerinin sonuçları farklı çıkmamıştır.

Çalışmadan elde edilen sonuçlar geçmiş çalışmaların sonuçlarıyla benzerlikler göstermektedir. Kavşağa tüm kollardan yaklaşan toplam şerit sayısı (TS) kavşak güvenliğini etkileyen en önemli parametre olarak bulunmuştur $(p=0,000 ; \beta=0,409)$. Kavşağa yaklaşan şerit sayısı arttıkça, kaza sayısı artmaktadır. Benzer birçok çalışmada şerit sayısındaki artışın kazaları arttırdığı sonucuna ulaşılmıştır [5,45-46,79]. Kavşağa giriş kollarındaki şerit sayısının fazla olması kavşak tasarımını zorlaştırmaktadır ve dönüşler için yeterli genişlikte düzenleme yapılmasını gerektirmektedir. İncelenen dönel kavşaklarda, orta ada çaplarının büyük olması nedeniyle, kavşak içerisindeki dönüş alanlarının daraldığı tespit edilmiştir. $\mathrm{Bu}$ durumun kaza sayısındaki artışta etkili olduğu düşünülmektedir. İlerideki çalışmalarda kavşak içinde tasarlanan şerit sayısının sola/sağa dönüş yapan ve karşıya geçen taşıt sayısı için yeterli olup olmadığı incelenerek daha detaylı sonuçlar elde edilebilir. Diğer bir önemli husus ise taşıtların kavşak kollarında mı yoksa kavşak içinde mi bekletildiğidir. İncelenen dönel kavşaklarda taşıtlar orta ada çevresinde bekleme yapmaktadır. Bu durumda sola dönen taşıtlar, düz giden taşıtların hareketlerini önemli ölçüde kısıtlayıp kaza riski arttırmaktadır. Dönel olmayan kavşaklarda yapılan gözlemlerde ise kavşak tasarımında bir sorun olmadığ1 buna karşın sürücülerin şerit kullanımından kaynaklanan problemlerin yaşandığı görülmüştür. Sağ şeritten kavşağa giren sürücülerin sola döndüğü ya da sol şeritten sağa dönüşler yapıldığı sahada tespit edilmiştir. Bu sorunun daha detaylı istatistiksel analizi için kavşaklarda kamera kaydı yapılarak kural ihlallerinin sıklıklarının tespit edilmesi önerilmektedir. Pratikte ise bu sorunu azaltmak için uyarı işaretleri ve denetimler arttırılabilir.

Kavşağa birincil kavşak kollarından giren birim otomobil eşdeğerinin (AYOGT) ikincil kavşak kollarından giren birim otomobil eşdeğerine (IYOGT) oranı (OYOGT) kavşak güvenliğini etkileyen diğer önemli parametredir $(p=-0,122 ; \beta=-0,031)$. Bu oran arttıkça kaza sayısı azalmaktadır. Literatürde birincil ve ikincil kavşak kollarındaki hacim değerlerinin etkisini ayrı ayrı inceleyen çalışma sayısı sınırlıdır. Torbic vd. [49] bu oranın artmasının yaya kazalarını arttırdığını bulmuştur. Lord ve Persuad [80] her iki hacim değerindeki ayrı ayrı artışın trafik kazalarını arttırdığı sonucuna ulaşmıştır. Diğer çalışmalarda kavşaktaki toplam trafik hacmi kazaları arttırmaktadır [5,8,21,49]. Bu çalışmada kavşağa tüm kollardan giren birim otomobil eşdeğeri (TYOGT) ile kavşağa tüm kollardan yaklaşan toplam şerit sayısı (TS) arasında yüksek korelasyon $(r=0.71)$ bulunduğu için modelleme aşamasında TYOGT yerine OYOGT değişkeni kullanılmıştır. OYOGT değerinin artması birincil ve ikincil kavşak kolu ayrımı belirginleştirmektedir. Bu oranın azalması ise her iki yönün trafik hacmi olarak birbirine yakınlaşması ve birincil/ikincil kavşak kolu ayrımının ortadan kalkması anlamına gelmektedir. Bu durumda benzer trafik hacmindeki kavşak kollarının kesiştiği durum ortaya çıkmaktadır. OYOGT azalırken kaza sayısının artması, kavşak kollarındaki sürücülerin önceliğin kendilerinde olduğunu düşünerek hareket etmesi ve kırmızı 1şık ihlali yaparak kazaya neden olması ile açıklanabilir. Sahada yapılan gözlemlerde bu tür ihlallerin çok fazla yaşandığını göstermiştir. Mersin'de henüz kullanımda olmayan kırmızı 1şık kamera denetimi faaliyete geçirilerek ışı ihlalleri ve kazalar azaltılabilir. Böyle bir yaptırım başlangıçta arkadan çarpma kazalarını arttırma ihtimali olsa da uzun vadede trafik güvenliği açısından faydalı olacaktır. 
Birincil kavşak kollarında orta refüj bulunması kaza sayısını anlamlı olarak azaltmaktadır. $\mathrm{Bu}$ sonuç trafik hacminin daha yoğun olduğu birincil kavşak kolundaki orta refüjün, sürücülerin daha dikkatli araç kullanmasında etkili olduğu ile açıklanabilir. Buna karşın literatürde Wang vd. [5] kavşak kollarındaki orta refüjün kaza sayıları üzerinde etkisi olmadığını bulmuştur. Geçmiş çalışmalarda sinyalize kavşaklardaki faz sayısının artmasının trafik güvenliğini olumsuz etkilediği bulunmuştur $[5,46]$. Bu çalışmada da aynı sonuç elde edilmiştir. Fakat bu durum istatistiksel olarak anlamlı çıkmamıştır.

Hızın trafik güvenliği üzerindeki olumsuz etkisi yadsınamaz bir gerçektir. Dong vd. [8] birincil ve ikincil kavşak kollarındaki hız limitlerinin artışııın, kaza sayısını arttırdığını bulmuştur. Bu çalışmada hız limitlerinin kaza sayıları üzerinde etkisi bulunmamıştır. Benzer şekilde kavşak kollarındaki hız limitlerinin aynı olup olmamasında bir etkisi bulunamamıştır. $\mathrm{Bu}$ noktada sürücülerin belirlenen hız limitlerine ne kadar uyduğu önem kazanmaktadır. $\mathrm{Bu}$ konuda daha net bir yargıya varabilmek için sahada ölçülen taşıt hızları ile kazalar arasındaki ilişkinin incelenmesi gerekmektedir. $\mathrm{Bu}$ çalışma kapsamında böyle bir firsat yaratılamamıştır. İlerideki çalışmalarda bu konunun incelenmesi önerilmektedir.

$\mathrm{Bu}$ çalışmada Mersin kent merkezinde dört kollu sinyalize kavşaklarda sadece taşıtların karışıtı̆ı trafik kazalarına etkileyen faktörler Poisson ve NB regresyon modelleri ile incelenmiştir. Mersin'de 2019 yllından itibaren 70 kavşakta dinamik kavşak yönetim sistemine geçilmiştir. İlerideki yıllarda buradan toplanacak verilerle daha çok kavşak ve y1l kullanılarak çalışmanın geliştirilmesi daha kapsamlı sonuçlar elde edilmesine olanak kılacaktır. İncelenen kavşak sayısının ve çalışma süresinin arttırılmasına ek olarak; hız limitleri yerine kavşaklarda ölçülen hız değerlerinin kullanılması geliştirilecek modellerin anlamlılığını iyileştirecektir. $\mathrm{Bu}$ iyileştirme yapılırken kullanılan modelde incelenen değişkenler arasına yaya kazaları ile birlikte yaya yoğunluğunu temsil eden bir parametrenin kullanılması modeli daha anlamlı kılacaktır.

\section{Semboller}

AIC : Akaike bilgi ölçütleri

AS : Kavşağa birincil kollardan yaklaşan şerit sayısı

AYOGT : Kavşağa ikincil kollarından giren YOGT

BIC: $\quad$ : Bayes bilgi ölçütleri

BOtE : Birim otomobil eşdeğeri

C : Sinyalizasyon döngü süresi

F : : Sinyalizasyon sistemindeki faz sayısı

FYOGT : AYOGT-IYOGT

IS : Kavşağa ikincil kollardan yaklaşan şerit sayısı

IYOGT : Kavşağa ikincil kavşak kollarından giren YOGT

KA : Kavşak alanı 


$\begin{array}{ll}\text { KCA } & \text { : Maksimum kavşak çarpıklık açısı } \\ \text { MY } & : \text { Maksimum yeşil süresi } \\ \text { NB } & : \text { Negatif binom } \\ \text { NY } & : \text { Nüfus yoğunluğu } \\ \text { OGT } & \text { : Ortalama günlük trafik } \\ \text { OM } & \text { : Ortalama kavşak mesafesi } \\ \text { OYOGT } & : \text { AYOGT/IYOGT } \\ \text { SAYOGT } & : \text { AYOGT/AS } \\ \text { SIYOGT } & : \text { IYOGT/IS } \\ \text { STYOGT } & : \text { TYOGT/TS } \\ \text { TS } & : \text { Kavşağa tüm kollardan yaklaşan şerit sayısı } \\ \text { TYOGT } & : \text { Kavşağa tüm kollardan giren YOGT } \\ \text { YOGT } & : \text { Yıllık ortalama günlük trafik }\end{array}$

\section{Kaynaklar}

[1] Türkiye İstatistik Enstitüsü. Karayolu Trafik Kaza İstatistikleri, 2017. Türkiye, 2018. http://www.tuik.gov.tr/PreHaberBultenleri.do?id=27668

[2] Türkiye Karayolları Genel Müdürlüğü. Trafik Kazaları Özeti 2017. Türkiye, 2018. http://www.kgm.gov.tr/Sayfalar/KGM/SiteTr/Istatistikler/TrafikveUlasim.aspx

[3] Persaud, B., Lord, D., Palmisano, J., Calibration and Transferability of Accident Prediction Models for Urban Intersections. Transportation Research Record: Journal of the Transportation Research Board, 1784, 57-64, 2002.

[4] Wong, S. C., Sze, N. N., Li, Y. C., Contributory Factors to Traffic Crashes at Signalized Intersections in Hong Kong. Accident Analysis \& Prevention, 39(6), 1107-1113, 2007.

[5] Wang, X., Abdel-Aty, M., Brady, P. A., Crash Estimation at Signalized Intersections: Significant Factors and Temporal Effect. Transportation Research Record, 1953(1), 10-20, 2006.

[6] Montella, A., Identifying Crash Contributory Factors at Urban Roundabouts and using Association Rules to Explore their Relationships to Different Crash Types. Accident Analysis \& Prevention, 43(4), 1451-1463, 2011.

[7] Pulugurtha, S. S., Sambhara, V. R., Pedestrian Crash Estimation Models for Signalized Intersections. Accident Analysis \& Prevention, 43(1), 439-446, 2011.

[8] Dong, C., Clarke, D. B., Yan, X., Khattak, A., Huang, B., Multivariate RandomParameters Zero-Inflated Negative Binomial Regression Model: An Application to 
Estimate Crash Frequencies at Intersections. Accident Analysis \& Prevention, 70, 320329, 2014.

[9] Poch, M., Mannering, F., Negative Binomial Analysis of Intersection-Accident Frequencies. Journal of Transportation Engineering, 122(2), 105-113, 1996.

[10] Kaygısız, Ö., Sümer, N., Kentsel Kavşaklardaki Elektronik Denetim Sistemlerinin Trafik Kazalarına Etkisi: Ankara Örneği. METU Journal of the Faculty of Architecture, 34(2), 225-244, 2017.

[11] Kaygısız, Ö., Şenbil, M., Şehir Planlamada Yol Ağı ve Kavşaklar Sorunu: Kazalar ve Kaza Çeşitlerinden Bir Bakış, Eskişehir Örneği. 2. Kentsel ve Bölgesel Araştırmalar Sempozyumu, Ankara, Türkiye, 2011.

[12] Tanyel, S., Koyuncu, M., Çalışkanelli, S. P., Sürücü Davranışlarının Sinyalize Kavşak Başarımı Üzerindeki Etkisi. Teknik Dergi, 29(5), 8563-8588, 2018.

[13] Çalışkanelli, S. P., Tanyel, S., Sinyalize Kavşaklarda Doygun Akım Değerinin İrdelenmesi. Teknik Dergi, 29(1), 8225-8248, 2017.

[14] Ewing, R., Dumbaugh, E., The Built Environment and Traffic Safety: A Review of Empirical Evidence. Journal of Planning Literature, 23(4), 347-367, 2009.

[15] Ebbecke, J. M., Schuster J. J., Areawide Impact of Traffic Control Devices. Transportation Research Record, 644, 54-57, 1977.

[16] Bissell, H. H., Neudorff, L. G., Criteria for Removing Traffic Signals. Compendium of Technical Papers, Institute of Transportation Engineers, Washington, DC, USA, 1980.

[17] Persaud, B., Hauer, E., Retting, R., Vallurupalli, R., Mucsi, K., Crash Reductions Related to Traffic Signal Removal in Philadelphia. Accident Analysis \& Prevention, 29(6), 803-810, 1997.

[18] Wong, S. C., Yang, H., Reserve Capacity of a Signal-Controlled Road Network. Transportation Research Part B: Methodological, 31(5), 397-402, 1997.

[19] Wong, C.K., Wong, S.C., Tong, C.O., A Lane-Based Optimization Method for the Multi-Period Analysis of Isolated Signal-Controlled Junctions. Transportmetrica, 2, 53-85, 2006.

[20] Elvik, R., A. B. Mysen, T. Vaa. Traffic Safety Handbook. Institute of Transport Economics. Norway, 1997.

[21] Greibe, P., Accident Prediction Models for Urban Roads. Accident Analysis \& Prevention, 35(2), 273-285, 2003.

[22] Brüde, U, Traffic Safety at Junctions, VTI Rapport, 366A, 1991.

[23] Vodahl, S. B., Giæver, T., Risiko ved Fotgjengerkryssinger, Report No: STF63 A86025, SINTEF Samferdselsteknikk, Trondheim, 1986.

[24] Lovegrove, G. R., Sayed, T., Macro-Level Collision Prediction Models for Evaluating Neighbourhood Traffic Safety. Canadian Journal of Civil Engineering, 33(5), 609-621, 2006. 
[25] Gluck, J. S., Levinson, H. S., Stover, V. G., Impacts of Access Management Techniques, No: 420, Transportation Research Board, 1999.

[26] Vogt, A., Crash Models for Rural Intersections: 4-Lane by 2-Lane Stop-Controlled and 2-Lane by 2-Lane Signalized. Federal Highway Administration, Washington, DC, USA 1999.

[27] Bauer, K. M., Harwood, D. W., Statistical Models of at-grade Intersection Accidents, No: FHWA-RD-96-125, 1996.

[28] Vogt, A., Bared, J., Accident Models for Two-Lane Rural Segments and Intersections. Transportation Research Record: Journal of the Transportation Research Board, (1635), 18-29, 1998.

[29] Federal Highway Association, Roundabouts: An Informational Guide, No: FHWARD-00-067, 2000.

[30] Elvik, R., Vaa, T., Hoye, A., Sorensen, M. (Eds.), The Handbook of Road Safety Measures. Emerald Group Publishing, 2009.

[31] Troutbeck, R. J., Capacity and Design of Traffic Circles in Australia. Transportation Research Record, 1398, 1993.

[32] Schoon, C., van Minnen, J., Safety of Roundabouts in The Netherlands. Traffic Engineering and Control, 35(3), 142-148, 1994.

[33] Rodegerdts, L., Roundabouts in the United States. Transportation Research Board, 572, 2007.

[34] Brown, M., The Design of Roundabouts, 1995.

[35] Rodegerdts, L. A., Cibor, A., Pochowski, A., Status of Roundabouts in North America, TRB Roundabout Conference, USA, 2008.

[36] Lenters, M. S., Safety Auditing Roundabouts, Transportation Research E-Circular, No: E-C083, 1-20, 2005.

[37] Spacek, P., Basis of the Swiss Design Standard for Roundabouts. Transportation Research Record: Journal of the Transportation Research Board, 1881, 27-35, 2004.

[38] Elvik, R., Effects on Road Safety of Converting Intersections to Roundabouts: Review of Evidence from Non-US Studies. Transportation Research Record: Journal of the Transportation Research Board, 1847, 1-10, 2003.

[39] Distefano, N., Leonardi, S., A List of Accident Scenarios for Three Legs Skewed Intersections. IATSS Research, 42(3), 97-104, 2018.

[40] Burchett, G. D., Maze, T. H., Rural Expressway Intersection Characteristics as Factors in Reducing Safety Performance. Transportation Research Record, 1953(1), 71-80, 2006.

[41] Zhong, X., Wang, Y., Zhong, L., Zhu, X., Jia, J., Zhao, M., Ma, J., Liu, X. (2007). Study on the Relationship of Intersection Design and Safety of Urban Unsignalized 
Intersection in China. In 3rd Urban Street Symposium, Transportation Research Board, Washington D.C., 2007.

[42] American Association of State Highway, and Transportation Officials, T., A Policy on Geometric Design of Highways and Streets, 2011.

[43] Pulugurtha, S. S., Nujjetty, A. P., Assessment of Models to Estimate Crashes at Intersections: With and without using Traffic Volume, No: 12-2880, 2012.

[44] Ladron de Guevara, F., S. P. Washington, and J. Oh, Forecasting Crashes at the Planning Level: Simultaneous Negative Binomial Crash Models Applied in Tucson, Arizona. In Transportation Research Record: Journal of the Transportation Research Board, 1897, 191-199, 2004.

[45] Lyon, C., Haq, A., Persaud, B., Kodama, S., Safety Performance Functions for Signalized Intersections in Large Urban Areas: Development and Application to Evaluation of Left-Turn Priority Treatment. Transportation Research Record: Journal of the Transportation Research Board, 1908, 165-171, 2005.

[46] Kumara, S., Chin, H., Application of Poisson Underreporting Model to Examine Crash Frequencies at Signalized Three-Legged Intersections. Transportation Research Record: Journal of the Transportation Research Board, 1908, 46-50, 2005.

[47] Oh, J., Washington, S., Choi, K., Development of Accident Prediction Models for Rural Highway Intersections. Transportation Research Record: Journal of the Transportation Research Board, 1897, 18-27, 2004.

[48] Lee, C., Abdel-Aty, M., Comprehensive Analysis of Vehicle-Pedestrian Crashes at Intersections in Florida. Accident Analysis \& Prevention, 37(4), 775-786, 2005.

[49] Torbic, D., Harwood, D., Bokenkroger, C., Srinivasan, R., Carter, D., Zegeer, C., Lyon, C., Pedestrian Safety Prediction Methodology for Urban Signalized intersections. Transportation Research Record: Journal of the Transportation Research Board, 2198, 65-74, 2010.

[50] Brüde, U., Larsson, J., The Safety of Cyclists at Roundabouts: A Comparison between Swedish, Danish and Dutch Results. Statens väg-och Transportforskningsinstitut, 1996.

[51] Jovanis, P. P., Chang, H. L., Modeling the Relationship of Accidents to Miles Traveled. Transportation Research Record, 1068, 42-51, 1986.

[52] Joshua, S. C., Garber, N. J., Estimating Truck Accident Rate and Involvements using Linear and Poisson Regression Models. Transportation Planning and Technology, 15(1), 41-58, 1990.

[53] Chin, H. C., Quddus, M. A., Applying the Random Effect Negative Binomial Model to Examine Traffic Accident Occurrence at Signalized Intersections. Accident Analysis \& Prevention, 35(2), 253-259, 2003.

[54] Miaou, S. P., Lum, H., Modeling Vehicle Accidents and Highway Geometric Design Relationships. Accident Analysis \& Prevention, 25(6), 689-709, 1993.

[55] Washington, S.P., Karlaftis, M.G., Mannering, F.L., Statistical and Econometric Methods for Transportation Data Analysis. CRC Press, New York, United States, 2003. 
[56] Greene, W. H., Accounting for Excess Zeros and Sample Selection in Poisson and Negative Binomial Regression Models, 1994.

[57] Maher, M. J., Summersgill, I., A Comprehensive Methodology for the Fitting of Predictive Accident Models. Accident Analysis \& Prevention, 28(3), 281-296, 1996.

[58] Abdel-Aty, M. A., Radwan, A. E., Modeling Traffic Accident Occurrence and Involvement. Accident Analysis \& Prevention, 32(5), 633-642, 2000.

[59] Hu, W., McCartt, A. T., Teoh, E. R. Effects of Red Light Camera Enforcement on Fatal Crashes in Large US Cities. Journal of safety research, 42(4), 277-282, 2011.

[60] Donnell, E. T., Porter, R. J. and Shankar, V. N. (2010). A Framework for Estimating the Safety Effects of Roadway Lighting at Intersections. Safety science, 48(10), 14361444, 2010.

[61] Kumara, S. S. P., Chin, H. C., Modeling Accident Occurrence at Signalized Tee Intersections with Special Emphasis on Excess Zeros. Traffic Injury Prevention, 4(1), 53-57, 2003.

[62] Malyshkina, N., Mannering, F., Zero-State Markov Switching Count-Data Models: An Empirical Assessment. Accident Analysis and Prevention 42 (1), 122-130, 2010.

[63] Qin, X., Ivan, J.N., Ravishankar, N., Selecting Exposure Measures in Crash Rate Prediction For Two-Lane Highway Segments. Accident Analysis and Prevention 36 (2), 183-191, 2004.

[64] Lord, D., Washington, S.P., Ivan, J.N., 2007. Further Notes on the Application of Zero Inflated Models in Highway Safety. Accident Analysis and Prevention 39(1), 53-57, 2007.

[65] Mitra, S., Washington, S., On the Significance of Omitted Variables in Intersection Crash Modeling. Accident Analysis \& Prevention, 49, 439-448, 2012.

[66] Wu, Z., Sharma, A., Mannering, F. L. and Wang, S., Safety Impacts of Signal-Warning Flashers and Speed Control at High-Speed Signalized Intersections. Accident Analysis \& Prevention, 54, 90-98, 2013.

[67] Haque, M. M., Chin, H. C. and Huang, H., Applying Bayesian Hierarchical Models to Examine Motorcycle Crashes at Signalized Intersections. Accident Analysis \& Prevention, 42(1), 203-212, 2010.

[68] Das, A., Abdel-Aty, M. A., A Combined Frequency-Severity Approach for the Analysis of Rear-End Crashes on Urban Arterials. Safety Science, 49(8-9), 1156-1163, 2011.

[69] Wang, X. ve Abdel-Aty, M., Temporal and Spatial Analyses of Rear-End Crashes at Signalized Intersections. Accident Analysis \& Prevention, 38(6), 1137-1150, 2006.

[70] Zhou, S., Sun, J., Li, K. P., Yang, X., Development of a Root Cause Degree Procedure for Measuring Intersection Safety Factors. Safety Science, 51(1), 257-266, 2013.

[71] Hels, T., Orozova-Bekkevold, I., The Effect of Roundabout Design Features on Cyclist Accident Rate. Accident Analysis \& Prevention, 39(2), 300-307, 2007. 
[72] Milton, J., Mannering, F., The Relationship Among Highway Geometrics, TrafficRelated Elements And Motor-Vehicle Accident Frequencies. Transportation, 25(4), 395-413, 1998.

[73] Greene, W. H., Econometric analysis. Pearson Education India, 2003.

[74] Ye, X., Pendyala, R. M., Washington, S. P., Konduri, K., Oh, J., A Simultaneous Equations Model of Crash Frequency by Collision Type for Rural Intersections. Safety science, 47(3), 443-452, 2009.

[75] Mersin Büyükşehir Belediyesi Ulaşım Dairesi Başkanlı̆̆ı, Mersin Büyükşehir Belediyesi Kentiçi ve Yakın Çevre Ulaşım Ana Planı Revizyonu Trafik Etüt ve Değerlendirme Sonuç Raporu, Mersin, Türkiye, 2015.

[76] Transportation Research Board, Highway Capacity Manual 2010, Transportation Research Board, National Research Council, Washington, DC, 2010.

[77] Montella, A., Roundabout in-service Safety Reviews: Safety Assessment Procedure. Transportation Research Record: Journal of the Transportation Research Board, 2019, 40-50, 2007.

[78] Kleiber, C., Zeileis, A., Visualizing Count Data Regressions using Rootograms. The American Statistician, 70(3), 296-303, 2016.

[79] Porter, B. E., England, K. J., Predicting Red-Light Running Behavior: A Traffic Safety Study in Three Urban Settings. Journal of Safety Research, 31(1), 1-8, 2000.

[80] Lord, D., Persaud, B., Accident Prediction Models with and without Trend: Application of the Generalized Estimating Equations Procedure. Transportation Research Record: Journal of the Transportation Research Board, 1717, 102-108, 2000. 
